Research article

\title{
SIMULATION OF THE TRANSMISSION BY VECTORS OF BLUETONGUE DISEASE AND ANALYSIS OF THE CONTROL STRATEGY
}

\author{
ĐURIĆ Spomenka ${ }^{1}$, MIRILOVIĆ Milorad ${ }^{1}$, MAGAŠ Vladimir ${ }^{1}$, BACIĆ Dragan ${ }^{1}$, \\ STANIMIROVIĆ Zoran ${ }^{1}$, STANOJEVIĆ Slobodan ${ }^{2}$, STANOJEVIĆ Slavoljub ${ }^{3 *}$
}

${ }^{1}$ Faculty of Veterinary Medicine, University of Belgrade, Bulevar oslobođenja 18, 11080 Belgrade, Serbia; ${ }^{2}$ Scientific Veterinary Institute of Serbia, Vojvode Toze 14, 11107 Belgrade, Serbia; ${ }^{3}$ Directorate of National Reference Laboratories, Batajnički drum 7, 11080 Zemun, Serbia

(Received 30 June, Accepted 04 September 2018)

Bluetongue disease is an infectious non-contagious disease of domestic and wild ruminants, transmitted by hematophagous insects of the genus Culicoides. In endemic areas the disease has a seasonal character, occurs usually in summer when the population of vectors is at its peak. Culicoides are active at temperatures in the range from $13^{\circ}$ to $35^{\circ} \mathrm{C}$. The replication of the virus stops when the environmental temperature is below $13^{\circ} \mathrm{C}$. It has been reported that the temperature and humidity of the environment affect to a great extent the biology of the vector and the survival of the virus in the reservoirs. During the summer, the number of infected cattle and sheep is directly dependent on the density of the population of the vector, the length of vectors' life-span, the temperature of the environment and by precipitation, the affinity of the vector to different hosts, and the ability of the vector to locate the host. Bluetongue has been spreading worldwide due to climatic changes and increasing average daily temperatures. The seasonal occurrences of the disease and the climate change have conditioned the need for adopting new strategies. The stochastic SEIRD mathematical model has been developed in order to simulate the transmission of the Bluetongue virus through the susceptible ruminant population on the territory of the Republic of Serbia, as well as to investigate the effect of climatic factors on the vector population and the magnitude of a possible epizootia. Besides the effects of climatic factors, we have analyzed a number of different approaches in the control of the disease based upon the vaccination of ruminants and control of vectors.

Key words: Bluetongue disease, simulation, control strategy, SEIRD model, Culicoides

\section{INTRODUCTION}

Bluetongue (BT) is an infectious disease of domestic and wild ruminants, caused by DNA Orbivirus, a member of Reoviridae family. Although most of the domestic, as well

\footnotetext{
*Corresponding author: e-mail: slavoljub.stanojevic@minpolj.gov.rs
} 
as wild ruminants are susceptible, the disease is most frequently observed in sheep. It is not a contagious disease and transmission depends on haematophagous insects that belong to Culicoides family. The epizootiological process and disease dynamics depend on the climate and inter-relationships between the virus, vector population and susceptible species. The capacity and vector competence are directly influenced by the external i.e. environmental factors and that is why BT is a seasonal disease. The virus that causes BT is not a contagious one and vertical transmission is not significant as far as epizootiology is concerned. BT incidence is highest in late summer when vector population is dense and active. In the environment, virus survival is the result of infection of vectors, as well as in susceptible species (ruminants and rodents). The virus can survive in the environment for 9 to 12 months without the presence of vectors and with no clinical cases in ruminants. This phenomenon is present during the winter and is well known as "virus hibernation" which means that the virus survives in the environment, waiting for the favorable season for the manifestation of BT. Cattle is the main reservoir of the virus since infection can last up to 300 days. The virus can survive in cattle during the winter or unfavorable summer period. Clinical signs, as well as the severity of the symptoms, depend on animal species and breed, animal age and virus virulence [1]. Haematophagous insects, Culicoides are not good fliers. They are mostly located close to the hatching place, near stables, lagoons filled with water, where they feed on animals during the so called gonotrophic life stage. However, wind can carry vectors several hundreds of kilometers and that is the main way BT spreads in nature [2]. In order to properly estimate the risk of seasonal BT occurrence in the Republic of Serbia, as well as to estimate its epizootic potential i.e. dynamics of the distribution of the disease, a stochastic method has been developed and applied in this study. The model, we have developed is based on, and connects climatic elements, vector population, susceptible animal species, and control measures. It emulates the transmission of BTV in a mixed population of cattle and sheep. The model incorporates as much as possible the data which reflect situation in The Republic of Serbia such as temperatures, vector and host population. The dependence of climatic factors such as average daily temperatures on parameters e.g. length of viremia, biting rate, ovipositiong rate, vector's death rate was included in the model and measured. Model simulates and gives the result about the possible influence of average temperatures on parameters which are relevant for diseases transmission. Sensitivity analyses were carried out to identify the most influential parameters on the disease transmission. Such model simulates the vector transmission of the disease during the day while transmission intensity i.e. density and vector capacity are influenced by climate which means variations of the average temperature during the day period. This model has been mostly developed in order to simulate BT transmission with the following vectors: Culicoides obsoletus and $C$. pulicarus complex since these two vector species are endemic in northern Europe and are dominant in Serbia [2]. On the other side, Culicoides immicola is the dominant vector for BT in Italy and in the Mediterranean region [3]. 


\section{MATERIALS AND METHODS}

\section{Stochastic SEIRD model}

According to the definition, a model is a simplified transformation (display) of the real environment, process or system. In essence, a model serves to reflect a real system, phenomenon or event based on experience, collected data, and opinions, as well as view of the experts. Basically, the selection of a model depends on the needs and time that are required in order to make a decision, the nature of the research and investigation, requested precision of the results, available data and finances $[4,5]$.

During epizootia simulation, animals go through different stages and at the same time, they became part of different groups. During the simulation process, the animals are selected and allocated to different groups: susceptible (S), latently infected (E), source of infection i.e. carrier (I), convalescent - immune (R) and dead (D). Graph 1 represents the structure of the model. During an epizootia, animals move from one group and compartment to another. The number of compartments varies depending on the complexity of the model, nature of interactions and rules that are simulated by the model $[6,7,8]$.

The model that was developed and applied in this study is based on the Reed-Frost recurrent formula:

$$
C_{t+1}=S_{t} *\left(1-(1-P)^{C_{t}}\right)
$$

where:

$\mathrm{C}_{\mathrm{t}+1}$ - number of new BT infected animals in the next time period $(\mathrm{t}+1)$

$\mathrm{S}_{\mathrm{t}}$ - number of susceptible animals in the previous time period, $\mathrm{t}$

$\mathrm{P}$ - probability of effective contact

$(1-\mathrm{P})$ - probability of an individual escape effective contact.

Application of this formula is based on the fact that each future status that a particular susceptible animal passes through; depends on the state of the animal in the previous stage. For example, the number of newly diagnosed cases (transfer from compartment $\mathrm{S}$ to compartment $\mathrm{E}$ ) depends on the status in the previous time interval $t_{0}$. The vector borne disease formula is partially modified in the "effective contact"part. This describes the number of effective contacts that have as a result disease transmission from carrier to susceptible animal. In this case the formula is as follows:

$$
C_{t+1}=S_{t} *\left(1-(1-V / T)^{C t}\right)
$$

where:

$\mathrm{V}$ - vector capacity,

$\mathrm{T}$ - total number of animals, in this case the total number of sheep and cattle.

The vector capacity is defined as the average number of potentially infective bites that will ultimately be delivered by all the vectors feeding on a single host in 1 day 
$[9,10]$. Vector capacity is a product of feeding, survival rate, and length of the extrinsic incubation period (EIP) and can be calculated as:

$\mathrm{V}=$ [Number of vectors feeding on the host per unit time] $\mathrm{x}$ [Probability the vector survives the EIP] x [Number of blood meals on people after EIP] [9].

Further development of formula includes following elements:

1. Probability a vector feeds on a host in one day : $a=$ host preference index $\mathrm{x}$ feeding frequency. Variable $\mathbf{a}$ is influenced by external temperature.

2. Vector density in relation to the host: $-\mathrm{m}$,

3. Vector competence: $b=$ "vector competence", the proportion of vectors ingesting an infective meal that successfully become infective,

4. Probability the vector will survive 1 day: $p=1$ /average expected time period of vector life span (influenced by environmental temperature),

5. Viral genesis rate - influenced by environmental temperature,

6. Duration of the extrinsic incubation period (days): $n$ or EIP) $=1 / \mathrm{v}_{\mathrm{r}}$,

7. $1 /(-\ln p)=$ duration of the vector's life, in days, after surviving the extrinsic incubation period (EIP).

The final formula for vector capacity is as follows:

$$
V=\frac{\boldsymbol{m} * \boldsymbol{a}^{2} * \boldsymbol{p}^{E I P} * b}{-\ln p}
$$

This formula could be used for the preparation of the Excel spreadsheet.

$[9,10]$. Such modified recurrent Reed-Frost formula defines the model and equilibrated rate of changing between different model compartments. In order to simulate the temperature variability, as well as the influence of temperature variability on vector density, external viral incubation period for the vectors, bite rates, survival of the vectors in the environment, and rate of vector egg hatching we used the Monte Carlo method and applied stochastic elements into the model.

Using functions of random numbers „NORM.INV(RAND 0 (mean,standard_dev)“, RAND $O$ and RANDRBETWEEN in MS that are in the Excel program package, on the basis of the statistical data extracted from „Hydrometeorological Institute“ of the Republic of Serbia on the average monthly temperatures and deviations from them, a temperature model as part of the basic model has been developed. Such model simulates daily temperature changes on the hypothetical region where the disease is spreading. Data obtained by this method, were in fact hypothetic temperatures and these values were the basis of developing a sub-model that simulates vector density at a daily level, average bite rate, hatching of the vector rate, rate of Culicoida development, as well as vectors death rate. The dynamic model of the vector population has been simulated by a series of differential equations as follows: 


$$
\begin{gathered}
\frac{d p_{a}}{d t}=m p_{i}-d_{a} p_{a} \\
\frac{d p_{i}}{d t}=b\left(1-\frac{p_{i}}{p_{\text {imax }}}\right) p_{a}-d_{i} p_{i}-m p_{i}
\end{gathered}
$$

where:

1. $d \mathrm{p}_{\mathrm{a}}$ - changing the number of adult vectors, during the time period $\mathrm{dt}$,

2. $\mathrm{dp}_{\mathrm{i}}$ - changing the number of immature vectors, during the time period $\mathrm{dt}$,

3. $\mathrm{p}_{\mathrm{a}}$ - number of mature vectors in the time interval $t$,

4. $\mathrm{p}_{\mathrm{i}}$ - number of immature vectors, in the time interval $\mathrm{t}$,

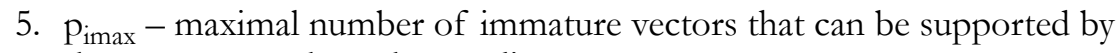
the ecosystem where they replicate.

6. $\mathrm{d}_{\mathrm{i}}$ - death rate of immature vectors,

7. $\mathrm{d}_{\mathrm{a}}$ - death rate of adult vectors,

8. $\mathrm{b}$ - vectors laying eggs rate.

At the same time, in order to present the SEIRD model dynamics of the susceptible animal population in the compartment (S) as realistic as possible, changes of animal numbers and densities that were influenced by birth rate and expected technology losses (mortality rate due to technology) as well as a result of the disease apart of BT, were simulated. Graph 1 shows the interaction of the SEIRD model with the model of the vector population.

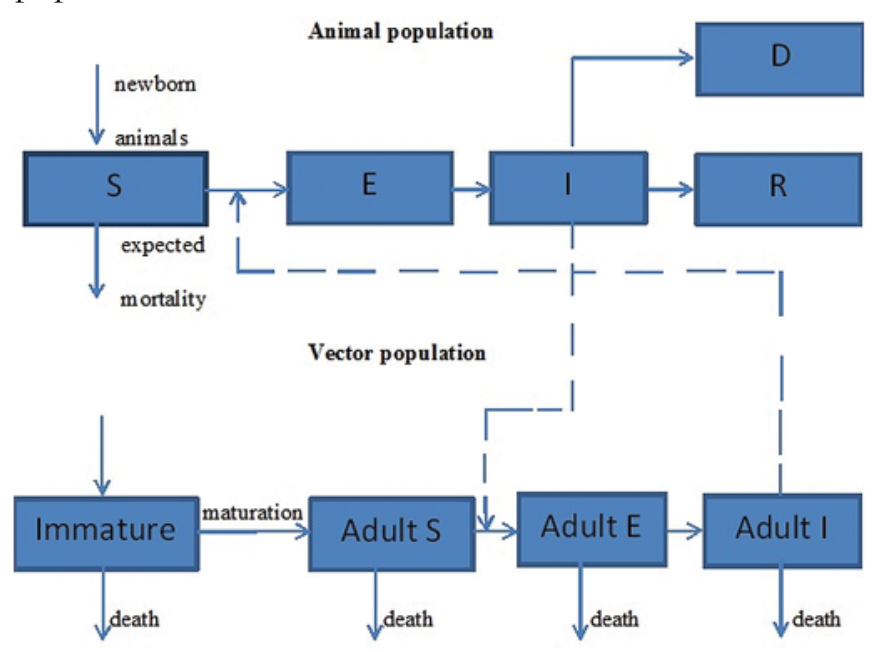

Graph 1. Vector population model and SEIRD BT model 
One of the components of the model is vaccination of the susceptible animals and maintaining of the heard immunity. The immune status of the herd has been simulated in order to evaluate the critical coverage of the vaccination that is required to stop the transmission of the disease and in order to compare the effects of disease control measures by using mass vaccination with the effects of vector density control. Herd immunity is the protection of the non-vaccinated animals (minority) that are surrounded by vaccinated (immune) animals (majority). The proportion of the vaccinated (immune) animals in the particular population for herd immunity to be achieved is variable and is not the same for different diseases. However, the principle of collective immunity is the same. Once a satisfactory level of vaccination coverage is achieved, by means of basic infection reproduction rate, vaccinated (immune) animals in the herd protect non-vaccinated animals as well as those that were not able to develop their own immune. [11,12]. Model parameters are given in Table 1.

For simulation purposes, software packages have been used as follows: MS Excel 2010, Resampling Stats for Excel 2007 and PopTools 3.2 (build 5). In total, 15 different scenarios have been processed. At the same time, analysis of the mathematical model sensitivity was carried out. Each scenario has been simulated for 5000 iterations.

In order to perform the statistical analysis of the results from this study, descriptive statistical data have been used. These data allowed us to describe the experimental results, which were obtained during checking of the applied sampling method. Descriptive statistical indicators that were used are as follows: central tendency measure, standard deviation, standard arithmetic mean error, interval of variation, 50 and 90 percentile. Regression analysis and determination of the Pearson's correlation coefficient has been used in order to determine the interrelationship between changes in the average temperatures, vector density (number of vectors) and their influence on the incidence level of BT in different scenarios.

\section{Setting up the scenarios}

The model covered 15 different possible scenarios. Most of them are based on the vaccination of the susceptible population, vector control and following possible consequences in the case of major, expected variations in the average monthly temperature. Variations of the average temperatures are the same as differences that were recorded by the Hydrometeorological Institute, during the time period from 2010 to 2017. In order to understand the influence of herd immunity and different vaccination coverage on the progress of the epizootia and disease dynamics, vaccination coverage has been set as 50\%,70\% and $90 \%$ of the total population. At the same time, effects of different vaccination coverage of sheep and cattle on the final outcome of the BT epizootia, were tested. In order to elucidate the importance and magnitude of the vector control in the model, in scenarios 8,9 and 10, vector intensity was lowered gradually by $10 \%$ and $20 \%$. 


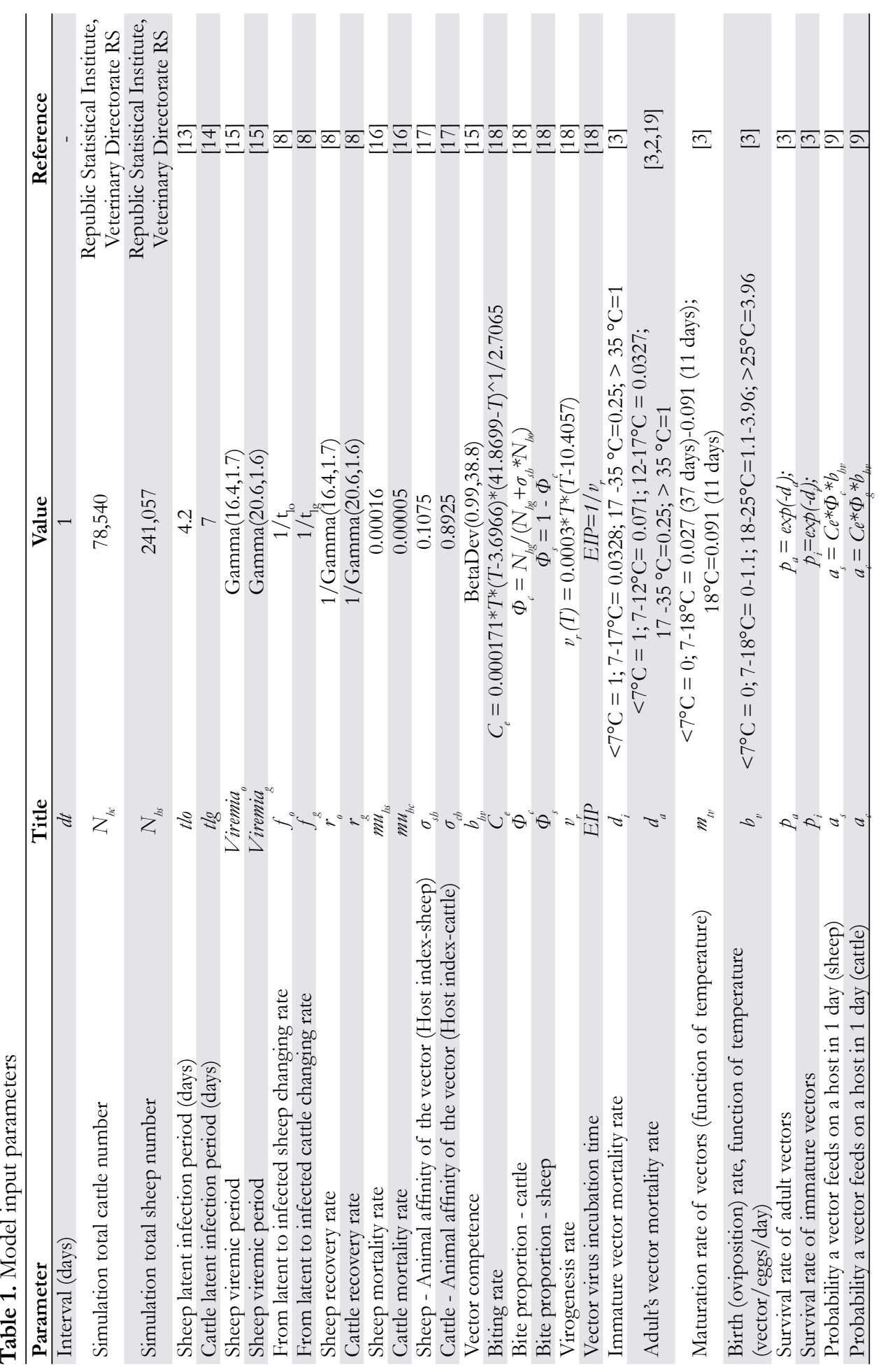


Table 2. Algorithm of the sensitivity model analysis as well as basic principles of the different scenarios simulations

\begin{tabular}{|c|c|c|c|c|}
\hline Scenario & $\begin{array}{c}\text { Sheep } \\
\text { vaccination } \\
\text { coverage }\end{array}$ & $\begin{array}{c}\text { Cattle } \\
\text { vaccination } \\
\text { coverage }\end{array}$ & $\begin{array}{c}* \mathrm{FRV} \\
\%\end{array}$ & Temperature changes \\
\hline Sensitivity analysis & $1.00 \%$ & $1.00 \%$ & $0.00 \%$ & $\mathrm{~T}^{\circ}=$ average daily temperature \\
\hline Sensitivity analysis & $0.00 \%$ & $0.00 \%$ & $1.00 \%$ & $\mathrm{~T}^{\circ}=$ average daily temperature \\
\hline Sensitivity analysis & $0.00 \%$ & $0.00 \%$ & $0.00 \%$ & $\mathrm{~T}^{\circ}=$ average daily temperature $+10 \% * \mathrm{STdev}$ \\
\hline Scenario 1 & $0.00 \%$ & $0.00 \%$ & $0.00 \%$ & $\mathrm{~T}^{\circ}=$ average daily temperature \\
\hline Scenario 2 & $50.00 \%$ & $50.00 \%$ & $0.00 \%$ & $\mathrm{~T}^{\circ}=$ average daily temperature \\
\hline Scenario 3 & $70.00 \%$ & $70.00 \%$ & $0.00 \%$ & $\mathrm{~T}^{\circ}=$ average daily temperature \\
\hline Scenario 4 & $90.00 \%$ & $90.00 \%$ & $0.00 \%$ & $\mathrm{~T}^{\circ}=$ average daily temperature \\
\hline Scenario 5 & $50.00 \%$ & $90.00 \%$ & $0.00 \%$ & $\mathrm{~T}^{\circ}=$ average daily temperature \\
\hline Scenario 6 & $90.00 \%$ & $50.00 \%$ & $0.00 \%$ & $\mathrm{~T}^{\circ}=$ average daily temperature \\
\hline Scenario 7 & $70.00 \%$ & $90.00 \%$ & $0.00 \%$ & $\mathrm{~T}^{\circ}=$ average daily temperature \\
\hline Scenario 8 & $70.00 \%$ & $70.00 \%$ & $10.00 \%$ & $\mathrm{~T}^{\circ}=$ average daily temperature \\
\hline Scenario 9 & $80.00 \%$ & $80.00 \%$ & $10.00 \%$ & $\mathrm{~T}^{\circ}=$ average daily temperature \\
\hline Scenario 10 & $80.00 \%$ & $80.00 \%$ & $20.00 \%$ & $\mathrm{~T}^{\circ}=$ average daily temperature \\
\hline Scenario 11 & $0.00 \%$ & $0.00 \%$ & $0.00 \%$ & $\mathrm{~T}^{\circ}=$ average daily temperature $+20 \% * \mathrm{STdev}$ \\
\hline Scenario 12 & $0.00 \%$ & $0.00 \%$ & $0.00 \%$ & $\mathrm{~T}^{\circ}=$ average daily temperature $+40 \% * \mathrm{STdev}$ \\
\hline Scenario 13 & $0.00 \%$ & $0.00 \%$ & $0.00 \%$ & $\mathrm{~T}^{\circ}=$ average daily temperature $+60 \% * \mathrm{STdev}$ \\
\hline Scenario 14 & $0.00 \%$ & $0.00 \%$ & $0.00 \%$ & $\mathrm{~T}^{\circ}=$ average daily temperature $+80 \% * \mathrm{STdev}$ \\
\hline
\end{tabular}

*FRV- vector number reduction factor $(\%)$

\section{Source of the data}

The number of sheep was obtained from the agricultural census in the R. Serbia and extracted from the Veterinary Directorate central data base. Information on the average monthly and annually temperatures as well as average temperature variations during 2010 to 2017 time period, were obtained from the Republic Hydrometeorological Institute of the R. Srbija (RHMZ) and extracted from RHMZ bulletin. Data on the dominant Culicoides species, space distribution in the R. Serbia, survival rate as well as information that are important for modeling of the susceptible host population, were obtained from the literature.

\section{RESULTS}

\section{Simulation results}

Results that were obtained during the simulation of the BT epizootics, show the possible dynamics of the disease in the case of vaccination, vector control and expected variations of average temperatures per year. Such dynamics is most probably the result of climate changes that we all face today. Graphs 2 and 3 show daily temperatures variations, changes in vector density (numbers), and laying eggs rate by adult vectors. Scenarios 11 to 15 , were analyzed according to the changes 
of the average year temperatures in R. Serbia. Such temperatures were recorded by the National Hydrometeorological Institute for the period 2010 - 2017. Changes of the temperature in the model measured $10 \%$ of the standard deviation for average winter, spring and fall temperatures (standard deviation values for the years that were analyzed were for winter, spring, summer and fall: $2.5^{\circ} \mathrm{C}, 3.95^{\circ} \mathrm{C}, 2.57{ }^{\circ} \mathrm{C}$ and 2.67 ${ }^{\circ} \mathrm{C}$, respectively) did not cause any significant changes in the number of diseased sheep and cattle, comparing to the starting point. However, changes in average temperature at the $20 \%, 40 \%, 60 \%, 80 \%$ and $100 \%$ level of standard deviation of the average winter, spring, summer and fall temperatures, cause significant changes in the number of diseased sheep and cattle.

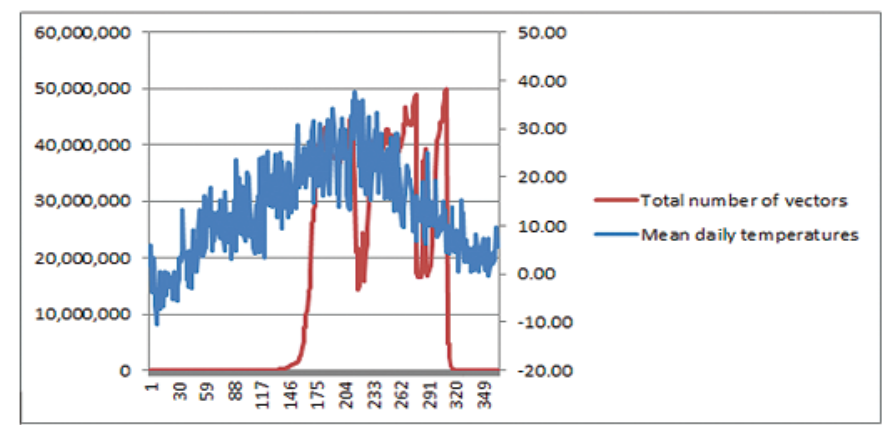

Graph 2. Average daily temperature and total number of vectors distribution

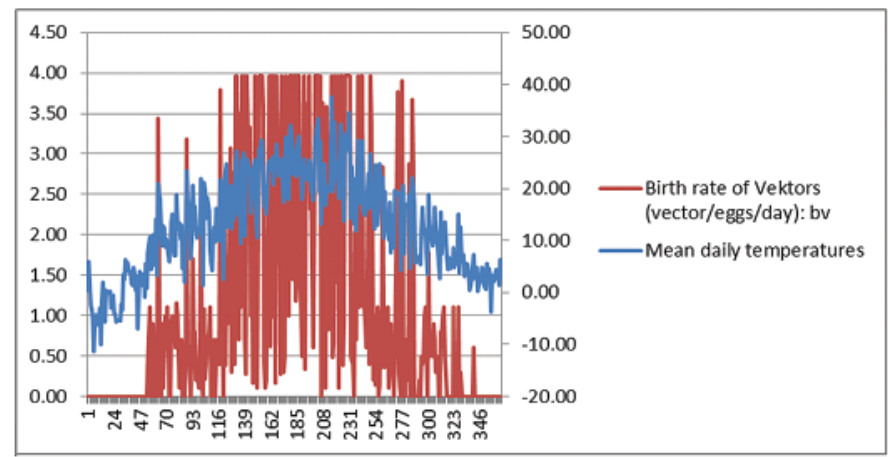

Graph 3. Average daily temperatures and vector egg laying rate distribution

Pearson's Correlation coefficient and results of the regression analysis are shown in Tables 3 and 4 as well as in Graph 4.

Table 3. Results of the correlation analysis of the relationship between temperature changes and cumulative incidence of BT in sheep

\begin{tabular}{lcc}
\hline & $\begin{array}{c}\text { Changes in average } \\
\text { year temperature }\end{array}$ & $\begin{array}{c}\text { Cumulative } \\
\text { incidence (CI) }\end{array}$ \\
\hline Change in average year temperature $\left(\mathrm{C}^{\circ}\right)$ & 1 & \\
Cumulative incidence & 0.986949959 & 1 \\
\hline
\end{tabular}


Table 4. Results of the regression analysis of the relationship between average daily temperatures and cumulative incidence of BT in sheep

\begin{tabular}{|c|c|c|c|c|c|c|}
\hline \multicolumn{3}{|c|}{ Regression Statistics } & & & & \\
\hline Multiple R & 0.99 & & & & & \\
\hline R Square & 0.97 & & & & & \\
\hline Adjusted R Square & 0.97 & & & & & \\
\hline Standard Error & 5.25 & & & & & \\
\hline Observations & 5 & & & & & \\
\hline \multicolumn{7}{|l|}{ ANOVA } \\
\hline & df & SS & MS & $\mathrm{F}$ & Significance F & \\
\hline Regression & 1 & 3109.34 & $3,109.34$ & 112.7 & 0.001786075 & \\
\hline Residual & 3 & 82.77 & 27.59 & & & \\
\hline \multirow[t]{2}{*}{ Total } & 4 & 3192.11 & & & & \\
\hline & Coefficients & SEE & t Stat & $\mathrm{P}$-value & Lower 95\% & Upper $95 \%$ \\
\hline Intercept & 835.19 & 5.5 & 151.82 & 6.30E-07 & 817.68 & 852.7 \\
\hline$\Delta$ temperature $\mathrm{C}^{\circ}$ & 30.14 & 2.84 & 10.62 & 0.00178608 & 21.11 & 39.18 \\
\hline
\end{tabular}

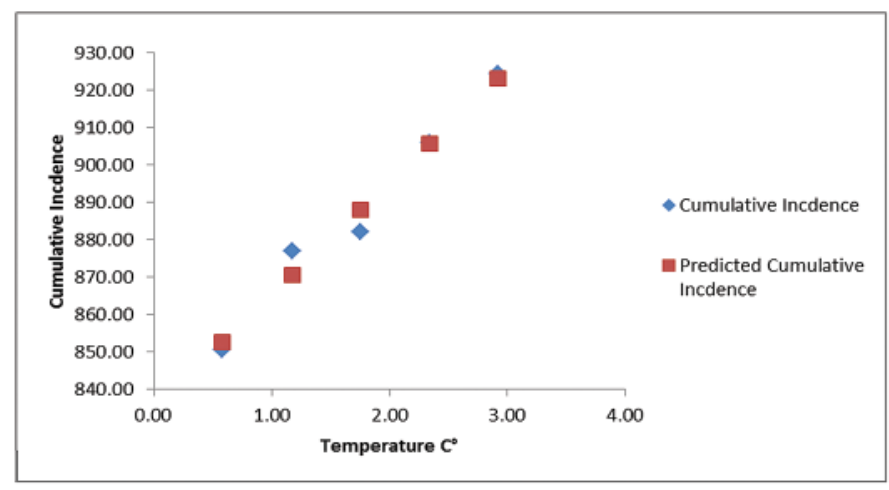

Graph 4. Graph of the dispersion of observed and expected cumulative incidence of BT in sheep-Line Fit Plot.

Tables 5, 6 and 7 as well as graphs 5, 6 and 7 show the results of the simulation of the distribution of BT in susceptible sheep and cattle population. Values of the cumulative BT incidence in cattle and sheep are shown. At the same time, values of the total sheep mortality due to BT have been shown. 
Table 5. Overview of the descriptive statistical indicators of the BT cumulative incidence in sheep, after 5000 iterations in the simulation

\begin{tabular}{lccccccc}
\hline Scenario & Mean & $\begin{array}{c}\text { Standard } \\
\text { deviation }\end{array}$ & CV & 50p & 95p & $\begin{array}{c}\text { Confidence } \\
\text { interval: LL }\end{array}$ & $\begin{array}{c}\text { Confidence } \\
\text { interval: UL }\end{array}$ \\
\hline SC1 & 862.76 & $1,359.16$ & $157.54 \%$ & 487.35 & $2,584.49$ & 825.09 & 900.44 \\
\hline SC2 & 180.67 & 201.18 & $111.35 \%$ & 115.90 & 574.75 & 175.09 & 186.24 \\
SC3 & 64.56 & 70.26 & $108.83 \%$ & 40.99 & 203.65 & 62.61 & 66.51 \\
\hline SC4 & 7.07 & 7.56 & $106.95 \%$ & 4.60 & 21.68 & 6.86 & 7.28 \\
\hline SC5 & 168.02 & 173.82 & $103.45 \%$ & 112.73 & 530.71 & 163.21 & 172.84 \\
\hline SC6 & 7.48 & 8.46 & $113.15 \%$ & 4.77 & 23.34 & 7.24 & 7.71 \\
\hline SC7 & 61.80 & 65.46 & $105.92 \%$ & 40.09 & 195.26 & 59.98 & 63.61 \\
\hline SC8 & 30.07 & 33.37 & $110.98 \%$ & 18.99 & 95.37 & 29.14 & 30.99 \\
\hline SC9 & 13.60 & 15.29 & $112.42 \%$ & 8.59 & 41.88 & 13.18 & 14.02 \\
\hline SC10 & 0.55 & 1.38 & $248.82 \%$ & 0.16 & 2.43 & 0.52 & 0.59 \\
\hline SC11 & 850.68 & $1,373.02$ & $161.40 \%$ & 477.37 & $2,573.27$ & 812.62 & 888.74 \\
\hline SC12 & 876.99 & $1,507.65$ & $171.91 \%$ & 473.01 & $2,667.63$ & 835.20 & 918.78 \\
\hline SC13 & 882.05 & $1,438.85$ & $163.13 \%$ & 490.79 & $2,765.24$ & 842.16 & 921.93 \\
\hline SC14 & 905.93 & $1,478.18$ & $163.17 \%$ & 513.54 & $2,682.28$ & 864.95 & 946.90 \\
\hline SC15 & 924.35 & $1,492.19$ & $161.43 \%$ & 498.73 & $2,880.16$ & 882.99 & 965.71 \\
\hline
\end{tabular}

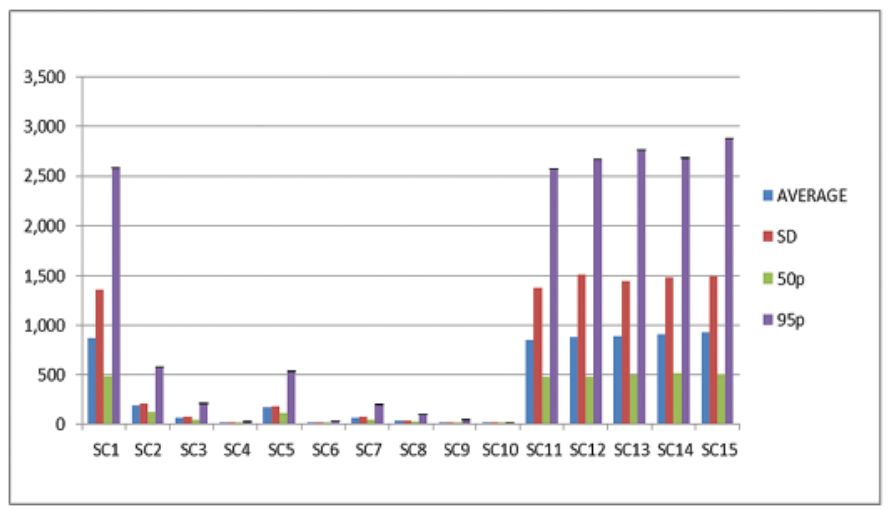

Graph 5. Overview of the descriptive statistical indicators of the BT cumulative incidence in sheep, after 5000 iterations in simulation. 
Table 6. Overview of the descriptive statistical indicators of the BT mortality rate in sheep, after 5000 iterations in the simulation

\begin{tabular}{lccccccc}
\hline Scenario & Mean & $\begin{array}{c}\text { Standard } \\
\text { deviation }\end{array}$ & $\mathbf{C V}$ & $\mathbf{5 0 p}$ & $\mathbf{9 5 p}$ & $\begin{array}{c}\text { Confidence } \\
\text { interval: } \mathbf{L L}\end{array}$ & $\begin{array}{c}\text { Confidence } \\
\text { interval: UL }\end{array}$ \\
\hline SC1 & 13.04 & 33.47 & $256.67 \%$ & 4.13 & 47.61 & 12.11 & 13.97 \\
\hline SC2 & 2.73 & 5.03 & $184.05 \%$ & 0.99 & 10.96 & 2.59 & 2.87 \\
SC3 & 0.96 & 1.71 & $177.42 \%$ & 0.36 & 3.96 & 0.92 & 1.01 \\
SC4 & 0.11 & 0.19 & $183.76 \%$ & 0.04 & 0.44 & 0.10 & 0.11 \\
SC5 & 2.50 & 4.60 & $183.97 \%$ & 0.89 & 10.19 & 2.37 & 2.63 \\
\hline SC6 & 0.11 & 0.22 & $197.25 \%$ & 0.04 & 0.44 & 0.11 & 0.12 \\
SC7 & 0.93 & 1.63 & $174.71 \%$ & 0.35 & 3.80 & 0.89 & 0.98 \\
\hline SC8 & 0.45 & 0.81 & $180.34 \%$ & 0.16 & 1.82 & 0.42 & 0.47 \\
SC9 & 0.20 & 0.36 & $176.64 \%$ & 0.07 & 0.85 & 0.19 & 0.21 \\
\hline SC10 & 0.01 & 0.03 & $313.21 \%$ & 0.00 & 0.03 & 0.01 & 0.01 \\
\hline SC11 & 12.19 & 32.86 & $269.50 \%$ & 4.03 & 50.33 & 11.28 & 13.10 \\
\hline SC12 & 12.33 & 32.51 & $263.79 \%$ & 3.84 & 47.36 & 11.42 & 13.23 \\
SC13 & 13.47 & 40.71 & $302.16 \%$ & 4.18 & 50.39 & 12.34 & 14.60 \\
\hline SC14 & 13.78 & 34.38 & $249.56 \%$ & 4.33 & 54.23 & 12.82 & 14.73 \\
\hline SC15 & 13.23 & 37.72 & $285.21 \%$ & 4.29 & 50.13 & 12.18 & 14.27 \\
\hline
\end{tabular}

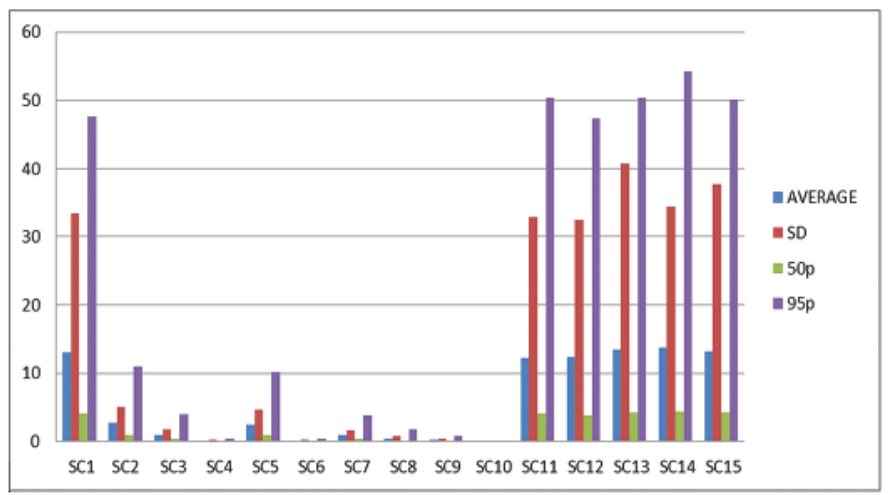

Graph 6. Overview of the descriptive statistical indicators of BT mortality rate in sheep, after 5000 iterations in the simulation. 
Table 7. Overview of the descriptive statistical indicators of BT cumulative incidence in cattle, after 5000 iterations in the simulation

\begin{tabular}{lccccccc}
\hline Scenario & Mean & $\begin{array}{c}\text { Standard } \\
\text { deviation }\end{array}$ & CV & 50p & 95p & $\begin{array}{c}\text { Confidence } \\
\text { interval: LL }\end{array}$ & $\begin{array}{c}\text { Confidence } \\
\text { interval: UL }\end{array}$ \\
\hline SC1 & $2,761.81$ & $5,569.05$ & $201.64 \%$ & 493.55 & $14,611.60$ & $2,607.45$ & $2,916.18$ \\
\hline SC2 & 706.21 & $1,565.27$ & $221.64 \%$ & 116.51 & $3,494.31$ & 662.82 & 749.59 \\
SC3 & 266.98 & 632.99 & $237.10 \%$ & 45.12 & $1,332.29$ & 249.43 & 284.52 \\
SC4 & 31.77 & 86.20 & $271.37 \%$ & 4.85 & 151.50 & 29.38 & 34.16 \\
SC5 & 30.88 & 80.35 & $260.24 \%$ & 4.51 & 155.18 & 28.65 & 33.10 \\
\hline SC6 & 712.09 & $1,504.66$ & $211.30 \%$ & 128.48 & $3,541.72$ & 670.39 & 753.80 \\
\hline SC7 & 32.64 & 88.52 & $271.22 \%$ & 5.12 & 151.61 & 30.19 & 35.09 \\
\hline SC8 & 136.13 & 375.01 & $275.47 \%$ & 19.73 & 657.01 & 125.74 & 146.53 \\
SC9 & 63.78 & 177.66 & $278.55 \%$ & 8.94 & 307.84 & 58.86 & 68.71 \\
\hline SC10 & 2.72 & 15.96 & $586.20 \%$ & 0.17 & 11.15 & 2.28 & 3.16 \\
\hline SC11 & $2,614.43$ & $5,347.98$ & $204.56 \%$ & 481.62 & $14,047.22$ & $2,466.19$ & $2,762.66$ \\
\hline SC12 & 2787.80 & 5672.51 & $203.48 \%$ & 470.81 & 15371.83 & 2630.57 & 2945.03 \\
\hline SC13 & $2,774.23$ & $5,593.43$ & $201.62 \%$ & 499.97 & $14,402.96$ & $2,619.20$ & $2,929.27$ \\
\hline SC14 & $2,909.21$ & $5,759.73$ & $197.98 \%$ & 543.74 & $14,915.55$ & $2,749.56$ & $3,068.86$ \\
\hline SC15 & $2,897.65$ & $5,780.64$ & $199.49 \%$ & 536.69 & $15,574.10$ & $2,737.43$ & $3,057.88$ \\
\hline
\end{tabular}

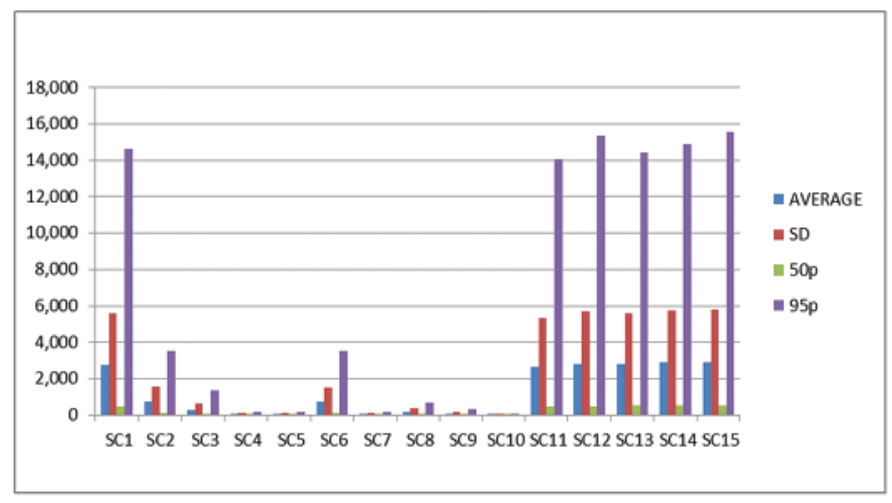

Graph 7. Overview of the descriptive statistical indicators of

BT cumulative incidence in cattle, after 5000 iterations in the simulation.

\section{Sensitivity analysis}

Sensitivity analysis of the model shows that the outcome of the scenarios on the epizootia dynamics, mostly depend on the changes of the model parameters that represent the number of the vectors present. The model has a high level of sensitivity as far as key parameters that are responsible for the epizootia, vector number simulation, susceptible animal species numbers and their interrelationships. Changes 
in temperature values in the model, at the $10 \%$ level compared to the standard deviation during several years (average values for winter, spring, and summer and fall temperatures during 2010 to 2017 time period) did not cause significant changes in the numbers of infected sheep and cattle, compared to the starting point. However, average temperature changes at the level of $20 \%$ in comparison to the standard deviation of the average temperatures for the same period, as a consequence had an increased numbers of diseased animals, comparing to the starting point. In order to determine how the model reacts to the changes in vaccination coverage, comparing to the starting point ( $0 \%$ vaccinated animals), $1 \%$ of the vaccinated animals (vaccine coverage) has been evaluated. Vaccination coverage at the level of $1 \%$, reduced the number of diseased sheep by $5.45 \%$ comparing to average level, which means $0.01 \%$, p95 (95 percentile) of the cumulative incidence of the starting values. In the case of cattle vaccination, for the same level of vaccination coverage (1\%), as a result of 5000 iterations, cumulative incidence was reduced by $6.20 \%$ of the average value which means $6.51 \%$ of the value p95 of the cumulative incidence comparing to the starting value. Testing of the model sensitivity as far as changes in the vector number are concerned, show that $1 \%$ reduction of the vector numbers, cause reduction of the diseased sheep by $8.12 \%$ of the average number of the cumulative incidence, which means $4.37 \%$ of the p95 value of the cumulative incidence at the starting point. In cattle, the same reduction in the vector number (1\%), caused reduction of the cumulative incidence by $4.37 \%$ comparing to the average number of the cumulative incidence at the starting point and $2.16 \%$ value of the p95. Mean values of the cumulative incidence, as well as total number of diseased animals, were calculated on the basis of the average values that were obtained after 5000 iterations in one simulation. Summary statistics of sensitivity analysis have shown in tables 8,9 and 10 .

Table 8. Model sensitivity analysis, changes in sheep cumulative incidence

\begin{tabular}{lcccc}
\hline Model sensitivity analysis & Mean & SD & 50p & 95p \\
\hline Starting point (vaccination coverage $\left.0 \%, \mathrm{t}^{\circ}=\mu\right)$ & 862.76 & $1,359.16$ & 487.35 & $2,584.49$ \\
1\% vaccination coverage & 818.15 & $1,263.94$ & 457.67 & $2,584.69$ \\
1\% reduced vector activity & 797.99 & $1,281.86$ & 444.29 & $2,477.15$ \\
Average daily temperatures $+10 \%$ St.Dev. & 858.70 & $1,400.29$ & 480.49 & $2,616.30$ \\
\hline
\end{tabular}

Table 9. Model sensitivity analysis, changes in sheep mortality numbers

\begin{tabular}{lcccc}
\hline Model sensitivity analysis & Mean & SD & 50p & 95p \\
\hline Starting point (vaccination coverage $\left.0 \%, \mathrm{t}^{\mathrm{o}}=\mu\right)$ & 13.04 & 33.47 & 4.13 & 47.61 \\
1\% vaccination coverage & 12.14 & 27.00 & 3.84 & 50.30 \\
1\% reduced vector activity & 11.61 & 24.28 & 4.01 & 48.14 \\
Average daily temperatures $+10 \%$ St.Dev. & 12.47 & 30.11 & 3.94 & 46.45 \\
\hline
\end{tabular}


Table 10. Model sensitivity analysis, changes in cattle cumulative incidence

\begin{tabular}{lcccc}
\hline Model sensitivity analysis & Average & SD & 50p & 95p \\
\hline Starting point (vaccination coverage $\left.0 \%, \mathrm{t}^{\mathrm{o}}=\mu\right)$ & $2,761.81$ & $5,569.05$ & 493.55 & $14,611.60$ \\
\hline 1\% vaccination coverage & $2,600.69$ & $5,384.39$ & 429.74 & $13,719.06$ \\
1\% reduced vector activity & $2,646.21$ & $5,387.25$ & 468.50 & $14,303.25$ \\
\hline Average daily temperatures $+10 \%$ St.Dev. & $2,688.40$ & $5,513.91$ & 510.99 & $13,890.26$ \\
\hline
\end{tabular}

\section{DISCUSSION}

By using the described method, it was possible to evaluate the risk of the seasonal occurrence of the BT epizootia, on the R. Serbia territory. In spite of the lack of more precise data on the epizootia magnitude as well as on the dynamics of the vector population, the model made it possible to evaluate basic assumptions for BT control. At the same time, such model can be used in order to analyze other vector borne diseases that are either already present or could occur in the near future in the Republic of Serbia. The model that has been described, gives an opportunity to further investigate and develop the BT spreading model especially considering climate changes due to global warming. During the model development, we were faced with the problem of lack of precise data on number, density as well as diversity of the vector population. However, in spite of the shortage of crucial information considering the number of the vector population, their distribution in the wide geographical region in the Republic of Serbia and data on the precipitation at the localities where Culicides samples were collected, it has been shown that there is a risk of seasonal occurrence of BT, that the disease most probably is enzootic in the wild ruminant population and that climate factors favor the survival of the Culicoides pulicaris, $C$. nubeculosus, $C$. obsoletus and C. parroti during the winter period of the year. In other words, vectors are enzootically present in Serbia. Such results have been confirmed by other authors, who performed field trials [2]. Such situation has an important impact on the possible magnitude of the epizootia as well as on the planning of the preventive measures [3].

Differences in the microclimate in different regions in the Republic of Serbia (Vojvodina, central Serbia and mountainous regions) indicate that there should be vector species diversification in different regions. The hot climate in certain regions can give adequate conditions for vectors to be endemically present. As a result, a vector could spread to other regions. At the same time, as the result of global warming, there is a real possibility that some exotic vector $C$ ulicides species, such as $C$. imicola and others, can appear. Since different Culicides species can differ as far as BT virus competence is concerned, the distribution and stabilization of the new and exotic vectors can change the epizootiological situation of BT in the Republic of Serbia [20].

On the basis of current knowledge on BT, it is clear that global distribution of BT is constantly changing. Because of that, mathematical models should be based as much 
as possible on the available data from the field. Application of the historical data, in the case of developing and defining parameters of the model, as a result could produce insufficient information and as a consequence, false and non-accurate conclusions. Taking that into consideration, further developing of the model, as well as expanding the program of BT monitoring can contribute to the quality of risk estimation and prediction of the epizootia in the future. If one considers the fact of existing climate changes by using mathematical modeling, it is possible to identify regions and locations with a high risk of BT occurrence. This means that by calculating the basic rate of reproduction $(R o),(R)$ and vector capacity for a particular geographical region, it would be possible to stratify locations and regions with a high risk of BT occurrence. At the same time, it would be possible to better plan control measures as far as BT is concerned [21,22].

In order to obtain the best answer to the question on the possible changes in the occurrence of certain vector species, which could have a higher competence level for BT virus, it is required to further develop the model and to intensify monitoring of BT that is already in place in the Republic of Serbia. Representative sample distribution of the vectors (Culicoides) has to ensure total coverage of the territory of Republic of Serbia. At the same time, such development of the model should be based on a better knowledge of climate factors, presence and density of the susceptible animal species as well as animal husbandry technology. Besides of the Culicoides species data, it is required to accumulate information about the number of vectors captured, sentinel farms locations and sampling techniques, and microclimate data during sampling procedure. In general, sampling should be performed in defined time intervals. Only in that case, it would be possible to support a regression dispersive vector model development. Such model would enable us better to understand the biology of the vector, estimated risk of BT occurrence, research on the BT dynamics and efficient control measures to be planned and applied [21].

One of the most important measures, as far as control of BT is concerned is the protection and prevention of the contacts between vectors and susceptible animals. The suggested control measures are vaccination, keeping animals in the stable during the night, usage of repellents and insecticides, drying ponds, swamps and small water accumulations, treating the lagoons and all the places that support the life cycle of the vectors i.e. Culicoides. However, vector control is not a simple task. Frequently, vector control is not possible in non-developed and rural areas that have extensive animal husbandry technologies, high temperatures and lot of rainfall. That means that vaccination and reduction of the vectors and animals contact are the first line of defense as far as control of BT is concerned. At the same time, that means that vaccination campaigns that are performed at the right time, as well as constant maintenance of the immune status of the susceptible animals as a result of high vaccination coverage, are best measures to control bluetongue. 


\section{Authors' contributions}

ĐS was responsible for all aspects of the work in ensuring that questions related to the accuracy and integrity of the work are appropriately investigated. MM gave contribution to data analysis and statistical interpretation of data. MV contributed to acquisition of data. BD was involved in revision of the article for intellectual content. SZ was responsible for critical evaluation and approval of the final version to be published. SSlobodan was responsible for feeding strategy and for the final revision of the article. SSlavoljub has made substantial contribution to conception and design and drafting the article. All authors read and approved the final manuscript.

\section{Declaration of conflicting interests}

The author(s) declared no potential conflicts of interest with respect to the research, authorship, and/or publication of this article.

\section{REFERENCES}

1. Radojičić S, Valčić M, Djuričić B: Infektivne bolesti životinja, specijalni deo. Beograd, Srbija: Naučna KMD, 2011.

2. Pavlović I, Vasić A, Bojkovski J, Simeunović P, Silaghi C, Veronesi E, Savuţa G, Oslobanu L, Dragoş A, Radanović O: Uticaj ekoloških faktora na rasprostranjenost i biodiverzitet Culicolides (Insecta: Ceratopogonidae). Ecologica, 2017, (85) 160-164.

3. Kelso JK, Milne GJ: Kelso JK, Milne GJ: A Spatial Simulation Model for the Dispersal of the Bluetongue Vector Culicoides brevitarsis in Australia. PLoS ONE 2014, 9(8). doi:10.1371/journal.pone.0104646.

4. Stanojević S: Simulacija epizootije klasične kuge svinja na teritoriji opština Sremska Mitrovica i Šid. Magistarska teza, Univerzitet u Beogradu-Fakultet veterinarske medicine 2014.

5. Thrusfield M: Veterinary epidemiology. Third edition. Blackwell Science Ltd; 2007, ISBN: 0-632-04851-4:340-341.

6. Stanojevic S, Valcic M, Radojicic S, Avramov S, Tambur Z: Simulation of a classical swine fever outbreak in rural areas of the Republic of Serbia. Veterinární medicína 2015, 60(10):553-556.

7. Keeling MJ, Rohani P. Modeling infectious diseases in humans and animals. Princeton University Press 2011, ISBN: 978-0-691-11617-4:7-8.

8. Vynnycky E, White R: An Introduction to infectious disease modelling. New York, NY: Oxford University Press 2010, ISBN 978-0-19-856-576-5:54-58.

9. Marquardt WC: Biology of Disease Vectors, second ed. Elsevier, Oxford, 2005, ISBN: 0-12-473276-3:190.

10. Fine, P.E.F.: Epidemiological principles of vector mediated transmission. Pp. 77-91 in J.J. McKelvey, Jr., B.F. Eldridge and K. Maramorosch (eds.), Vectors of disease agents. Praeger Scientific, New York, 1981. 
11. Stanojević, Slavoljub G: Evaluacija epizootioloških metoda u postupku određivanja obuhvata imunizacije protiv klasične kuge svinja u Republici Srbiji. PhD diss., Univerzitet u Beogradu-Fakultet veterinarske medicine; 2016.

12. Nishiura H, Dietz K, Eichner M: The earliest notes on the reproduction number in relation to herd immunity: Theophil Lotz and smallpox vaccination. J Theor Biol 2006, 241:964-7.

13. Worwa G, Hilbe M, Chaignat V, Hofmann MA, Griot C, Ehrensperger F, Doherr MG, Thür B: Virological and pathological findings in Bluetongue virus serotype 8 infected sheep. Vet Microbiology 2010, 144:264-273.

14. Singer RS, MacLachlan NJ, Carpenter TE: Maximal Predicted Duration of Viremia in Bluetongue Virus-Infected Cattle. J Vet Diagn Invest 2001 13:43-49.

15. Græsbøll K: Simulating spread of Bluetongue Virus by flying vectors between hosts on pasture, Modelling spread of Bluetongue and other vector borne diseases in Denmark and evaluation of intervention strategies. Kgs. Lyngby: Technical University of Denmark 2012, 285.

16. Gagić A: Animalni otpad u Bosni i Hercegovini-Značaj, porijeklo, kategorije i količine/ Animal Waste in Bosnia and Herzegovina-Significance, Origin, Category and Quantity. In Proceedings 2012, 21:41-63.

17. Elbers AR, Meiswinkel R: Culicoides (Diptera: Ceratopogonidae) host preferences and biting rates in the Netherlands: comparing cattle, sheep and the black-light suction trap. Veterinary Parasitology 2014, 205:330-337.

18. Napp S, Gubbins S, Calistri P, Allepuz A, Alba A, García-Bocanegra I, Giovannini A, Casal J: Quantitative assessment of the probability of bluetongue virus overwintering by horizontal transmission: application to Germany. Veterinary Research 2011, $42: 4$.

19. Carpenter S, Wilson A, Barber J, Veronesi E, Mellor P, Venter G, Gubbins S: Temperature dependence of the extrinsic incubation period of orbiviruses in Culicoides biting midges. PloS One 2011, 6(11):e27987.

20. Paweska JT, Venter GJ, Mellor PS: Vector competence of South African culicoides species for bluetongue virus serotype 1 (BTV-1) with special reference to the effect of temperature on the rate of virus replication in C. Imicola and C. Bolitinos. Med Vet Entomol 2002, 16 (1):10-21.

21. Selvaraju G, Balasubramaniam A, Rajendran D, Kannan D, Geetha M: Multiple linear regression model for forecasting Bluetongue disease outbreak in sheep of North-west agroclimatic zone of Tamil Nadu, India: 2013, Veterinary World 6(6):321-324

22. Mayo C, Shelley C, MacLachlan NJ, Gardner I, Hartley D, Barker C: A deterministic model to quantify risk and guide mitigation strategies to reduce bluetongue virus transmission in California dairy cattle. PloS One 2016, 11 (11):e0165806. 


\section{SIMULACIJA PRENOŠENJA VIRUSA PLAVOG JEZIKA VEKTORIMA I ANALIZA STRATEGIJE KONTROLE BOLESTI}

ĐURIĆ Spomenka, MIRILOVIĆ Milorad, MAGAŠ Vladimir, BACIĆ Dragan, STANIMIROVIĆ Zoran, STANOJEVIĆ Slobodan, STANOJEVIĆ Slavoljub

Bolest plavog jezika je virusno infektivno nekontagiozno oboljenje domaćih i divljih preživara, koje se prenosi hematofagnim insektima iz roda Culicoides. U endemskim područjima, bolest se javlja sezonski, obično u kasno leto kada je populacija vektora najbrojnija. Vektori iz roda Culicoides su aktivni na temperaturama između $13^{\circ}$ $35^{\circ} \mathrm{C}$, a sama replikacija virusa prestaje kada spoljna temperatura padne ispod $13^{\circ} \mathrm{C}$. Primećeno je da spoljna temperatura ambijenta i vlažnost sredine imaju značajan uticaj na biologiju vektora i opstanak virusa u rezervoarima. Tokom rizičnog perioda godine, broj inficiranih goveda i ovaca direktno je uslovljen gustinom populacije vektora, dužinom života vektora, temperaturom sredine i padavinama, afinitetom vektora prema različitim domaćinima i sposobnošću vektora da locira domaćina. U poslednjih nekoliko godina, došlo je do značajnog širenja bolesti plavog jezika u svetu, što je svakako uslovljeno klimatskim promenama i rastom prosečnih dnevnih temperatura. Sezonsko pojavljivanje bolesti i klimatske promene uslovile su potrebu za prilagođavanje kontrolnih strategija. Stohastički SEIRD matematički model je razvijen kako bi se izvršila simulacija širenja virusa bolesti plavog jezika kroz prijemčivu populaciju i ispitao uticaj klimatskih faktora na dinamiku epizootije. Pored analize uticaja klimatskih faktora, urađena je analiza nekoliko različitih pristupa u kontroli bolesti baziranih na vakcinaciji preživara i kontroli vektora. 